\title{
PREPARATION AND PROPERTIES OF SOME NEW DERIVATIVES OF THE OCTAHALODIRHENATE(III) ION
}

\author{
R. R. HENDRIKSMA \\ Inorganic Chemistry Department, State University of Utrecht, Croesestraat 77 A, The Netherlands
}

(Received 23 June 1971; in revised form 29 September 1971)

\begin{abstract}
Starting with $\left[\left(n-\mathrm{C}_{4} \mathrm{H}_{9}\right)_{4} \mathrm{~N}\right]_{2} \quad\left[\mathrm{Re}_{2} \mathrm{Cl}_{8}\right]$ the following compounds were synthesized: $[(n$ $\left.\left.\mathrm{C}_{4} \mathrm{H}_{9}\right)_{4} \mathrm{X}\right]_{2}\left[\mathrm{Re}_{2} \mathrm{Cl}_{8}\right]$ with $\mathrm{X}=\mathrm{P}$, As, Sb; $\left[\left(n-\mathrm{C}_{4} \mathrm{H}_{9}\right) \mathrm{N}\right]_{2}\left[\mathrm{Re}_{2}(\mathrm{SeCN})_{8}\right]$ and $\left[\left(n-\mathrm{C}_{4} \mathrm{H}_{8}\right)_{4} \mathrm{~N}\right]_{2}\left[\operatorname{Re}_{2}(\mathrm{CN})_{8}\right]$. Analytical data, spectral properties and magnetic susceptibilities are reported. The properties of the compounds $\left[\left(n-\mathrm{C}_{4} \mathrm{H}_{9}\right)_{4} \mathrm{X}_{2}\left[\mathrm{Re}_{2} \mathrm{Cl}_{8}\right]\right.$ are analogous to those of the starting material, but the selenocyanato and the cyanato complexes are different.
\end{abstract}

\section{INTRODUCTION}

THE COORDINATION chemistry of rhenium in its lower oxidation states II-V, and more particularly in the oxidation state III has been the subject of much confusion and misinterpretation. Only recently, as a result of careful reinvestigations [1-8] of older claims [9-13], certain basic facts have become clearly established. Generally the $\operatorname{Re}(\mathrm{III})$ compounds are characterized by the occurrence of the $\operatorname{Re}_{3} X_{9}$ and the $\operatorname{Re}_{2} X_{8}{ }^{2-}$ group, in which $X=C l$ and $B r$.

In this paper an investigation is described of the complexes which were obtained by reaction of the $\left[\mathrm{Re}_{2} \mathrm{Cl}_{8}{ }^{2-}\right]$ ion with large group $\mathrm{V}$ cations. Some preliminary experiments concerning the substitution of $\mathrm{SeCN}^{-}$and $\mathrm{CN}^{-}$in the $\mathrm{Re}$ (III) compounds are also reported. The selenocyanato and cyanato complexes were synthesized as a part of a program dealing with special stacking patterns of square rhenium complexes in crystalline phases.

\section{EXPERIMENTAL}

Reagents and solvents preparation

$\left[\left(n-\mathrm{C}_{4} \mathrm{H}_{9}\right)_{4} \mathrm{~N}\right]_{2}\left[\mathrm{Re}_{2} \mathrm{Cl}_{8}\right]$ was prepared as previously described[14]. KSeCN was prepared by

1. J. Chatt and G. A. Rowe, J. chem. Soc., 4019 (1962).

2. N. P. Johnson and G. Wilkinson, ibid. 1054 (1964).

3. F. A. Cotton and J. F. Mague, Inorg. Chem. 3, 1094 (1964).

4. F. A. Cotton and J. F. Mague, ibid. 3, 1402 (1964).

5. F. A. Cotton and S. J. Lippard, ibid. 4, 59 (1965).

6. F. A. Cotton and S. J. Lippard, ibid. 4, 508 (1965).

7. N. F. Curtis and W. R. Robinson, ibid. 4, $326(1965)$.

8. F. A. Cotton and C. B. Harris, ibid. 4, 330 (1965).

9. F. A. Cotton and B. F. G. Johnson, ibid. 3, 780 (1964).

10. M. Freni and V. Valenti, J. inorg: nucl. Chem. 16, 240 (1961).

11. R. Colton, R. Levitus and G. Wilkinson, J. chem. Soc., 1421 (1960).

12. V. G. Tronev and S. M. Bondin, Khim. Redkikh. Elementov. akad. nauk S.S.S.R. 1, 40 (1954).

13. G. K. Babeshkina and V. G. Tronev, Zh. neorg. Khim. 7, 715 (1962).

14. F. A. Cotton and N. F. Curtis, Inorg. Chem. 4, 1696 (1965). 
reaction of $\mathrm{KCN}$ with Se under dry nitrogen[15]. [ $\left.\left(\mathrm{C}_{6} \mathrm{H}_{5}\right)_{4} \mathrm{Sb}\right] \mathrm{Cl}$ was prepared by the reaction of $\mathrm{Sb}\left(\mathrm{C}_{6} \mathrm{H}_{5}\right)_{3}$ with $\mathrm{AlCl}_{3}$ and $\mathrm{C}_{6} \mathrm{H}_{5} \mathrm{Cl}$ under dry nitrogen, but the reaction conditions differ from those previously described [16].

\section{PREPARATION}

$\left[\mathrm{Re}_{2} \mathrm{Cl}_{8}\right]\left[\left(\mathrm{C}_{6} \mathrm{H}_{3}\right)_{4} \mathrm{As}\right]_{2}$. Stirring $0.60 \mathrm{~g}$ of $\left[\left(n-\mathrm{C}_{4} \mathrm{H}_{8}\right)_{4} \mathrm{~N}\right]_{2}\left[\mathrm{Re}_{2} \mathrm{Cl}_{8}\right]$ with $0.65 \mathrm{~g}$ of $\left[\mathrm{As}\left(\mathrm{C}_{6} \mathrm{H}_{5}\right)_{4}\right] \mathrm{Cl}$ in $50 \mathrm{ml}$ of methanol (containing $1 \mathrm{ml}$ of concentrated aqueous $\mathrm{HCl}$ per $100 \mathrm{ml}$ ) yielded a blue precipitate after $4 \mathrm{hr}$. The precipitate was filtered off, washed with ethanol $(25 \mathrm{ml})$, and diethylether $(150 \mathrm{ml})$, and then dried under vacuum at $80^{\circ} \mathrm{C}$ for $4 \mathrm{hr}$; yield 90 per cent. $\left[\operatorname{Re}_{2} \mathrm{Cl}_{8}\right]\left[\left(\mathrm{C}_{6} \mathrm{H}_{5}\right)_{4} \mathrm{P}\right]_{2}$. Prepared as $\left[\mathrm{Re}_{2} \mathrm{Cl}_{8}\right]\left[\left(\mathrm{C}_{6} \mathrm{H}_{5}\right)_{4} \mathrm{As}\right]_{2}$, yield 80 per cent. $\left[\mathrm{Re}_{2} \mathrm{Cl}_{8}\right]\left[\left(\mathrm{C}_{6} \mathrm{H}_{5}\right)_{4} \mathrm{Sb}\right]_{2}$. No reaction occurred with $\left[\left(\mathrm{C}_{6} \mathrm{H}_{5}\right)_{4} \mathrm{Sb}\right] \mathrm{Cl}$ in acidified methanol. The following method was successful.

Potassiumperrhenate, $2.0 \mathrm{~g}$, and sodium chloride, $2.0 \mathrm{~g}$ were heated in $40 \mathrm{ml}$ of 50 per cent aqueous hypophosphorus acid for $10 \mathrm{hr}$ at about $90^{\circ} .5 \mathrm{~g}$ of tetraphenylstiboniumchloride in $75 \mathrm{ml}$ of $6 \mathrm{nHCL}$, was added to the resulting dark solution, and heating was continued for $12 \mathrm{hr}$. The hot solution was filtered, yielding the crude blue product which was washed with $20 \mathrm{ml}$ of $6 \mathrm{nHCl}$ and three $20 \mathrm{ml}$ portions of diethylether, and finally dried under vacuum at $80^{\circ}$ for $8 \mathrm{hr}$; yield 35 per cent.

$\left[\mathrm{Re}_{2}(\mathrm{SeCN})_{8}\right]\left[\left(\mathrm{C}_{4} \mathrm{H}_{9}\right)_{4} \mathrm{~N}\right]_{2}$. Formation of this compound was studied in two different solvents.

(a) Reaction in alcohol. $\left[\mathrm{Re}_{2} \mathrm{Cl}_{8}\right]\left[\left(n-\mathrm{C}_{4} \mathrm{H}_{9}\right)_{4} \mathrm{~N}\right]_{2} 0 \cdot 15 \mathrm{~g}$, was dissolved in $10 \mathrm{ml}$ alcohol, $0.29 \mathrm{~g} \mathrm{KSeCN}$ in $50 \mathrm{ml}$ alcohol and the reaction mixture was stirred under dry nitrogen for $24 \mathrm{hr}$. During this time a deep purple compound separated which was filtered off, washed with alcohol, water and diethylether and dried under vacuum at $80^{\circ}$ for $8 \mathrm{hr}$.

(b) Reaction in acetonitrile. The reaction was carried out as described above, but no spontaneous precipitation occured. The deep purple solution was evaporated till dryness on a steambath; and the solid was washed with three $30 \mathrm{ml}$ portions of diethylether and dried under vacuum at $80^{\circ}$ for $8 \mathrm{hr}$. Analyses of the products obtained under (a) and (b) are quite different.

\section{Other reactions}

(a) The reaction of $\left[\left(n-\mathrm{C}_{4} \mathrm{H}_{3}\right)_{4} \mathrm{~N}\right]_{2}\left[\mathrm{Re}_{2} \mathrm{Cl}_{8}\right]$ with $\mathrm{KCN}$ in acidified methanol gave a product, from which the analyses could not be interpreted.

(b) Hydrogen peroxide ( $1 \mathrm{ml}$ of a 30 per cent solution) was added to an acetonitrile solution ( $20 \mathrm{ml}$ ) containing $0 \cdot 10 \mathrm{~g}\left[\left(n-\mathrm{C}_{4} \mathrm{H}_{9}\right)_{4} \mathrm{~N}\right]_{2}\left[\mathrm{Re}_{2}(\mathrm{SeCN})_{8}\right]$. After stirring for $3 \mathrm{hr}$ the solution became colourless. Then the solution was evaporated and a white product separated. The i.r. spectrum of this compound showed a strong band at $910 \mathrm{~cm}^{-1}$ assigned to $\nu(\mathrm{Re}-\mathrm{O})$ characteristic of the $\mathrm{ReO}_{4}{ }^{-}$group.

\section{PHYSICAL MEASUREMENTS AND ANALYSES}

Analyses were carried out by the Micro-Analytical Department of Organisch Chemisch Instituut TNO, Croesestraat 79, Utrecht. Infrared spectra were recorded in the range $4000-400 \mathrm{~cm}^{-1}$ using the Hitachi EPI-G 81 spectrophotometer as Nujol mulls sandwiched between potassium bromide plates. Diffuse Reflectance spectra of the solid compounds were obtained with Shimadzu MP $50-\mathrm{L}$ ratio recording spectrophotometer in the $250-2500 \mathrm{~nm}$ region, using magnesium oxide as a reference. Transmittance spectra were recorded on the same apparatus in $1 \mathrm{~cm}$ cells with equal thickness of the solvents in the reference beam of the apparatus.

Magnetic susceptibility measurements were performed by the Faraday method. The measurements were carried out at four different field strength. The field was calibrated with $\mathrm{CoHg}(\mathrm{CNS})_{4}$. Diamagnetic corrections were estimated from Pascal's constants and the magnetic moments were calculated using the expression:

$$
\mu_{\mathrm{eff}}=2 \cdot 84\left(\chi_{m}{ }^{\mathrm{corr}} T\right)^{1 / 2} \text {. }
$$

15. G. R. Waitkins and R. Shutt, Inorg. Syntheses, p. 186. McGraw-Hill, London (1946).

16. G. G. Long and L. D. Friedman, J. Org. Met. Chem. 12, 443 (1968). 


\section{RESULTS AND DISCUSSION}

\section{General}

In Table 1 the coordination compounds are listed together with their analytical results, colour and decomposition points. In all instances products isolated were insoluble in nonpolar solvents, but in some instances slightly soluble in acetonitrile and acetone. The reaction product with $\mathrm{KCN}$ is insoluble in all solvents we have tried.

Table 1. Chemical analyses, colours, decomposition points

\begin{tabular}{|c|c|c|c|c|c|c|c|c|c|c|}
\hline \multirow[b]{2}{*}{ Compound } & \multicolumn{2}{|c|}{$\% \mathrm{C}$} & \multicolumn{2}{|c|}{$\% \mathrm{H}$} & \multicolumn{2}{|c|}{$\% \mathrm{~N}$} & \multicolumn{2}{|c|}{$\% \cdot \mathrm{Cl}$} & \multirow{2}{*}{ colour } & \multirow{2}{*}{$\begin{array}{l}\text { decomp } \\
\text { point }{ }^{\circ} \mathrm{C}\end{array}$} \\
\hline & found & calc & found & calc & found & calc & found & calc & & \\
\hline$\left[\mathrm{Re}_{2} \mathrm{Cl}_{4}\right]\left[\left(\mathrm{C}_{6} \mathrm{H}_{5}\right)_{4} \mathrm{As}\right]_{2}$ & $40 \cdot 35$ & $40 \cdot 50$ & $2 \cdot 72$ & $2 \cdot 81$ & & & $20 \cdot 21$ & 19.97 & blue & 200 \\
\hline$\left[\mathrm{Re}_{2} \mathrm{Cl}_{8}\right]\left[\left(\mathrm{C}_{6} \mathrm{H}_{5}\right)_{4} \mathrm{P}\right]_{2}$ & $42 \cdot 91$ & $43 \cdot 18$ & $3 \cdot 40$ & $3 \cdot 20$ & & & $21 \cdot 40$ & $21 \cdot 29$ & blue & 200 \\
\hline$\left[\mathrm{Re}_{2} \mathrm{Cl}_{8}\right]\left[\left(\mathrm{C}_{6} \mathrm{H}_{3}\right)_{4} \mathrm{Sb}\right]_{2}$ & $38 \cdot 12$ & 37.99 & $2 \cdot 62$ & $2 \cdot 64$ & & & 18.81 & $18 \cdot 73$ & pale blue & 200 \\
\hline$\left[\mathrm{Re}_{2} \mathrm{Cl}_{8}\right]\left[\left(\mathrm{C}_{4} \mathrm{H}_{9}\right)_{4} \mathrm{~N}\right]_{2}$ & 33.95 & 33.68 & $6 \cdot 48$ & $6 \cdot 31$ & $2 \cdot 40$ & $2 \cdot 45$ & $24 \cdot 61$ & 24.91 & deep blue & 200 \\
\hline$\left[\operatorname{Re}_{2}(\mathrm{SeCN})_{4}\right]\left[\left(\mathrm{C}_{4} \mathrm{H}_{4}\right)_{4} \mathrm{~N}\right]_{2}{ }^{*}$ & $28 \cdot 11$ & $28 \cdot 30$ & $4 \cdot 29$ & $4 \cdot 25$ & $8 \cdot 16$ & $8 \cdot 25$ & & & deep purple & le 140 \\
\hline Substitution with $C N$ & $13 \cdot 71$ & & $1 \cdot 27$ & & & & & & black & 200 \\
\hline
\end{tabular}

* Reaction in acetonitrile.

\section{Ligand field spectra}

(a) Treatment of the bonding in the $\left[\mathrm{Re}_{2} \mathrm{Cl}_{8}\right]^{2-}$ ion. The $\left[\mathrm{Re}_{2} \mathrm{Cl}_{8}\right]^{2 \cdot}$ species consist of two parallel $\mathrm{ReCl}_{4}$ units connected by a $\mathrm{Re}$ to Re bond [Fig. 1].

We set aside the $d_{x^{2-y^{2}}}, p_{x}, p_{y}$ and $s$ orbitals of the valence shell of each rhenium atom for use in $\sigma$ bonding to the $\mathrm{Cl}$ atoms. Taking the $\mathrm{Re}-\mathrm{Re}$ line as $z$ axis we have the atomic orbitals $d_{z^{2}}$ and $p_{z}$ with $\sigma$ symmetry, $d_{x y}, d_{y z}$ with $\pi$ symmetry and $d_{x y}$ with $\delta$ symmetry. The atomic orbitals used for the Re-Re bonding are the $d_{z^{2}}-p_{z}$ hybride orbitals which can form a pair of $\sigma$ bonds. A pair of $\pi$ bonds can be formed by overlap of the two sets of $\pi$ atomic orbitals. Finally, a $\delta$ bond can be formed by overlap of the $\delta$ atomic orbitals. The $\delta$ component restricts rotation in just such a way as to favor the eclipsed configuration; the $\delta$

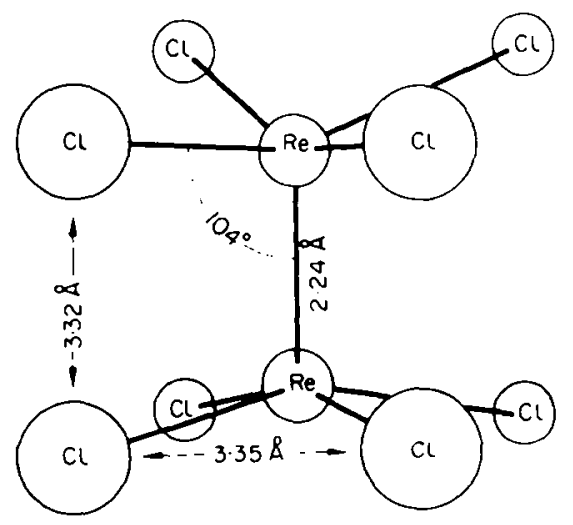

Fig. 1. Structure of the $\left[\operatorname{Re}_{2} \mathrm{Cl}_{\mathrm{B}}\right]^{2-}$ ion. 
overlap is maximal for this configuration and goes to zero for the staggered configuration [18, see Fig. 2].

In addition to the bonding $\left(\sigma, \pi^{2}, \delta\right)$ and antibonding $\left(\sigma^{*}, \pi^{* 2}, \delta^{*}\right)$ orbitals, there are two approximately nonbonding orbitals of $\sigma$ type, $\sigma_{n}(1)$ and $\sigma_{n}(2)$.
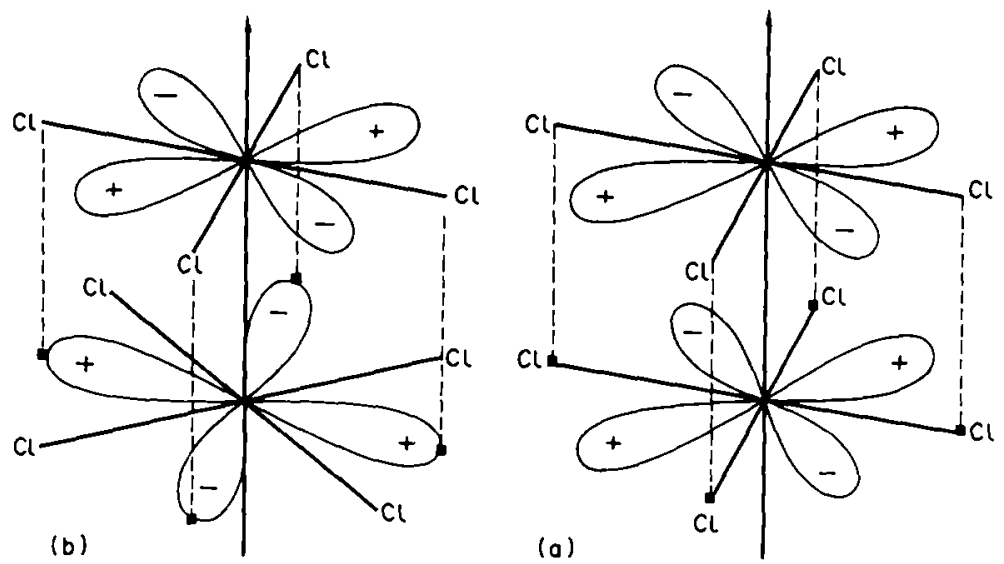

Fig. 2. A sketch showing how $\delta$ overlap depends on rotational angle: (a) eclypsed configuration with maximum overlap. (b) staggered configuration having zero overlap.

A simple energy level diagram for the $\left[\mathrm{Re}_{2} \mathrm{Cl}_{8}\right]^{2-}$ ion based on the extended Huckel theory is given in Fig. 3[19] as a help in discussing the spectra of the $\left[\mathrm{Re}_{2} \mathrm{Cl}_{8}\right]^{2-}$ species.

(b) Interpretation of the spectra. Band maxima, assignments and calculated values of the oscillator strengths are given in Table 2.

The oscillator strength is calculated with the formula

$$
f=4.6 \times 10^{-9} \epsilon_{\max } \Delta \nu[20]
$$

$\epsilon_{\max }=$ the decadic molar extinction coefficient at the band maximum.

$\Delta \nu=$ the halfbandwidth, is the width of the band in $\mathrm{cm}^{-1}$ where $\epsilon=\left(\epsilon_{\max } / 2\right)$.

For the higher energy peaks, $\Delta \nu$ is estimated by resolution of the observed envelope into Gaussian peaks.

The low energy, electric-dipole-forbidden transition at $14.500 \mathrm{~cm}^{-1}$ has been previously assigned as the ${ }^{1} B_{2 y} \rightarrow^{1} A_{2 u}\left(\delta \rightarrow \sigma_{n}(1)\right)$ transition. This assignment was based on very qualitative theoretical considerations [17].

The difference between the observed and calculated transition energy, $\sim 4000$ $\mathrm{cm}^{-1}$, is probably due in part to the neglect of penetration effects on the Re atomic orbitals, and in part to the neglect of interelectronic repulsion energies (calculation pertain only to one-electron orbitals). Both of these factors would tend to make the calculated energy higher, as is observed.

17. F. A. Cotton, Inorg. Chem. 4, 334 (1965).

18. F. A. Cotton, Acc. chem. Res. 2, (8), 240 (1964).

19. F. A. Cotton and C. B. Harris, Inorg. Chem. 6, 924 (1967).

20. A. B. P. Lever, Inorg. Electronic Spectroscopy, p. 124. Elsevier, London (1968). 


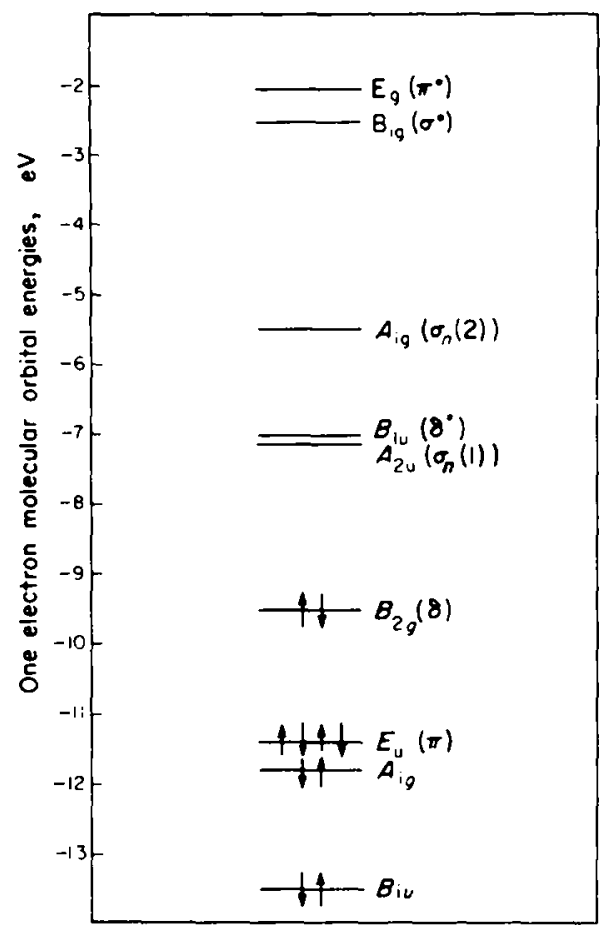

Fig. 3. A partial MO diagram for the $\left[\mathrm{Re}_{2} \mathrm{Cl}_{\mathbf{R}}\right]^{2-}$ ion.

Table 2.

\begin{tabular}{|c|c|c|c|c|c|}
\hline \multirow[t]{2}{*}{ Compounds } & \multirow[t]{2}{*}{ State } & \multicolumn{4}{|c|}{ Band maxima $\left(\mathrm{cm}^{-1}\right)$, assignments, oscillator strengths } \\
\hline & & ${ }^{1} B_{2 v} \rightarrow{ }^{1} B_{1 u}$ & ${ }^{1} E u \rightarrow{ }^{\prime} A_{2 u}$ & ${ }^{\prime} B_{2 u} \rightarrow{ }^{\prime} A_{2 u}$ & Other maxima \\
\hline \multirow[t]{2}{*}[\mathrm{Re}_{2}\mathrm{Cl}_{\mathrm{x}}]{$\left[\left(n-\mathrm{C}_{4} \mathrm{H}_{4}\right)_{4} \mathrm{~N}\right]_{2}$} & in $\mathrm{CH}_{3} \mathrm{OH}$ & $\begin{array}{c}39.000 \\
f=0.17 \pm 0.05\end{array}$ & $\begin{array}{c}32 \cdot 5(00 \\
f=0 \cdot 15 \pm 0.05\end{array}$ & $\begin{array}{l}14 \cdot 700 \\
f<0 \cdot 1\end{array}$ & $21 \cdot 000(w) ; 17 \cdot 500(\mathrm{sh})$ \\
\hline & solidt & $34 \cdot 480(s h)$ & $30 \cdot 300(\mathrm{~m})$ & $15.5(0)(v . s t)$ & \\
\hline \multirow[t]{2}{*}[\mathrm{Re}_{2}\mathrm{Cl}_{x}]{$\left[\left(\mathrm{C}_{6} \mathrm{H}_{5}\right)_{4} \mathrm{P}\right]_{2}$} & in $\mathrm{CH}_{3} \mathrm{OH}$ & $\begin{array}{c}37.900 \\
f=0.26 \pm 0.05\end{array}$ & $\begin{array}{c}32 \cdot 500 \\
f=0 \cdot 17 \pm 0 \cdot 05\end{array}$ & $\begin{array}{l}14.800 \\
f<0 \cdot 1\end{array}$ & $21 \cdot 100(w): 17 \cdot 500(\mathrm{sh})$ \\
\hline & solid & $35 \cdot 000(s h)$ & $30 \cdot 0 \times 10(\mathrm{~m})$ & 14.700 (v.st.) & \\
\hline & in $\mathrm{CH}_{3} \mathrm{OH}$ & $\begin{array}{c}38.200 \\
f=0.34 \pm 0.05\end{array}$ & $\begin{array}{c}32 \cdot 500 \\
f=0 \cdot 19 \pm 0.05\end{array}$ & $\begin{array}{l}14.700 \\
f<0.1\end{array}$ & $21 \cdot 100(\mathrm{~m}): 17 \cdot 200(\mathrm{sh})$ \\
\hline$\left[\mathrm{Re}_{2} \mathrm{Cl}_{8}\right]\left[\left(\mathrm{C}_{6} \mathrm{H}_{5}\right)_{4} \mathrm{As}\right]_{2}$ & solid & $36 \cdot 300(s h)$ & $29 \cdot 800(\mathrm{~m})$ & $14 \cdot 700$ (v.st.) & \\
\hline$\left[\mathrm{Re}_{2} \mathrm{Cl}_{\mathrm{x}}\right]\left[\left(\mathrm{C}_{5} \mathrm{H}_{5}\right)_{4} \mathrm{Sb}\right]_{2}$ & $\begin{array}{c}\text { in } \mathrm{CH}_{3} \mathrm{OH} \\
\text { solid }\end{array}$ & $\begin{array}{c}38 \cdot 000 \\
f=0 \cdot 12 \pm 0.05 \\
37 \cdot 000\end{array}$ & $\begin{array}{l}32.500 \\
f<0.1\end{array}$ & $\begin{array}{c}14.800 \\
f<0 \cdot 1 \\
14.800 \text { (v.st.) }\end{array}$ & $21 \cdot 270(w): 17 \cdot 500(s h)$ \\
\hline
\end{tabular}

*absorption spectra in acidified methanol.

†diffuse reflectance using magnesium oxide as a reference.

$\mathrm{sh}=$ shoulder: $\mathrm{m}=$ medium $; \mathrm{w}=$ weak and $\mathrm{v} . \mathbf{s t}$. = very strong.

Inspection of Table 2 shows, that the ${ }^{1} B_{2 g} \rightarrow{ }^{1} A_{2 u}$ transition is much more intense in the solid state spectrum than in the solution spectrum. This phenomenon shows the main disadvantage of the diffuse reflectance spectra, that it is difficult to obtain any information about the intensity of absorption. One cannot 
necessarily assume that because one band appears stronger than another it has a higher oscillator strength.

Apparent band intensities vary appreciably according to the state of subdivision of the sample and whether or not it is mixed with an inert diluent.

The two transitions at 32.500 and $38.000 \mathrm{~cm}^{-1}$ have oscillator strengths $>0 \cdot 1$, which is characteristic for electric-dipole-allowed transitions. An exception is the ${ }^{1} B_{2 \sigma} \rightarrow{ }^{1} B_{1 u}$ transition in the spectrum of $\left[\mathrm{Re}_{2} \mathrm{Cl}_{8}\right]\left[\left(\mathrm{C}_{6} \mathrm{H}_{5}\right)_{4} \mathrm{Sb}\right]_{2}$. The $32.500 \mathrm{~cm}^{-1}$ band is assigned to a ${ }^{1} B_{2 g} \rightarrow{ }^{1} B_{1 u}\left(\delta \leftarrow \delta^{*}\right)$ transition. Both the ${ }^{1} B_{2 g} \rightarrow{ }^{1} E_{g}$ and the ${ }^{1} E_{u} \rightarrow{ }^{1} B_{1 u}$ assignments can be ruled out. Such assignments would require an inversion of the $B_{2 g}$ and $E_{u}(\delta$ and $\pi)$ molecular orbitals. This means that the interaction of the $\operatorname{Re} \delta$ orbitals would be greater than that of the $\operatorname{Re} \pi$ orbitals. Clearly this is unreasonable. Also the assignment ${ }^{1} E_{u} \rightarrow{ }^{1} A_{2 u}$ would require an inversion of the $E_{g}$ and $B_{2 g}$ orbitals. A measurement of the polarization of the band could certainly distinguish between the ${ }^{1} B_{2 g} \rightarrow{ }^{1} B_{1 u}$ and ${ }^{1} E_{u} \rightarrow{ }^{1} A_{2 u}$ assignments, since the former is $z$ polarized while the latter is $x, y$ polarized.

Assigning this transition as ${ }^{1} A_{1 g} \rightarrow^{1} A_{2 u}$ is also highly unlikely because this means that the energy difference between the $\sigma$ and nonbonding $\sigma$ orbitals would be less than the difference between the $\delta$ and $\delta^{*}$ orbitals. The transition appearing at $38.000 \mathrm{~cm}^{-1}$ is in all likelihood a ${ }^{1} E_{u} \rightarrow^{1} A_{2 u}\left(\pi \rightarrow \sigma_{n}(1)\right)$ transition.

Further inspection of Table 2 shows, that there is a marked shift especially for the transitions ${ }^{1} B_{2 g} \rightarrow{ }^{1} B_{1 u}$ and ${ }^{1} E_{u} \rightarrow{ }^{\prime} A_{2 u}$ to lower wave numbers going from the solution spectrum to the solid state spectrum. A possible explanation for this phenomenon is, that the $\left[\mathrm{Re}_{2} \mathrm{Cl}_{8}\right]^{2-}$ ion in $\mathrm{CH}_{3} \mathrm{OH}$ solution will be solvated with $\mathrm{CH}_{3} \mathrm{OH}$ molecules. The $\mathrm{CH}_{3} \mathrm{OH}$ molecule acts as a stronger ligand than the other cations $\left(\left[\left(n-\mathrm{C}_{4} \mathrm{H}_{9}\right)_{4} \mathrm{~N}\right]^{+}\right.$, etc.) which causes a shift of the energy-levels in the diagram. Figure 4 shows the complete solution-spectrum recorded in acidified methanol for the $\left[\operatorname{Re}_{2}(\operatorname{SeCN})_{8}\right]^{2-}$ ion. This spectrum is rather different from the solution-spectrum of the $\left[\mathrm{Re}_{2} \mathrm{Cl}_{8}\right]^{2-}$ ion also given in Fig. 4. This does not provide positive evidence, that the structure of $\left[\mathrm{Re}_{2}(\mathrm{SeCN})_{8}\right]^{2-}$ is different from the $\left[\mathrm{Re}_{2} \mathrm{Cl}_{8}\right]^{2-}$ structure. To elucidate the exact structure of this complex X-ray analysis is necessary. For this purpose we are trying to make the complex crystalline.

\section{Magnetic measurements}

From Pascal's constants [21] for the cations and chlorine atoms, we estimated the diamagnetic part of the susceptibility. We observed that, while there was a small residual paramagnetism after correction, the $\left[\mathrm{Re}_{2} \mathrm{Cl}_{8}\right]^{2-}$ ion was essentially not paramagnetic. This means that the $\left[\mathrm{Re}_{2} \mathrm{Cl}_{8}\right]^{2-}$ ion has no unpaired electrons. This is in agreement with the stated ground state configuration of $\sigma^{2} \pi^{4} \delta^{2}$.

\section{I.R. spectra}

I.R. spectra were recorded in the range $4000-400 \mathrm{~cm}^{-1}$. The i.r. spectrum of $\left[\mathrm{Re}_{2}(\mathrm{SeCN})_{8}\right]\left[\left(n-\mathrm{C}_{4} \mathrm{H}_{9}\right)_{4} \mathrm{~N}\right]_{2}$ is given in Fig. 5 . The selenocyanate $\mathrm{C}-\mathrm{N}$ stretching frequency was observed as a very strong band at $2050 \mathrm{~cm}^{-1}$. A distinction between selenocyanato and isoselenocyanato complexes cannot be made with the 


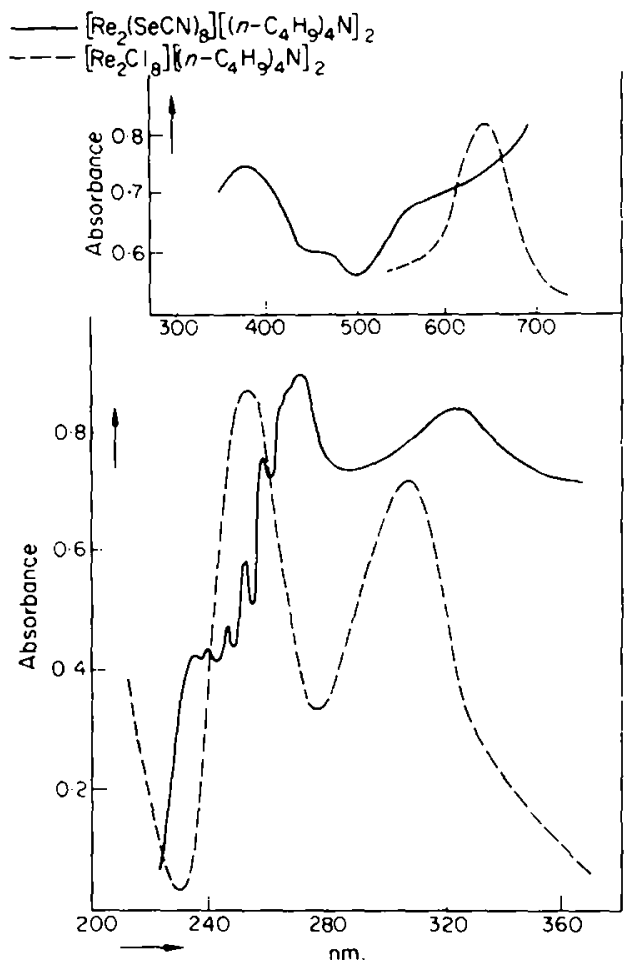

Fig. 4. Absorption spectra of the $\left[\operatorname{Re}_{2}(\operatorname{SeCN})_{8}\right]^{2-}$ and $\left[\operatorname{Re}_{2} C_{4}\right]^{2 \cdots}$ ion in acidified methanol.

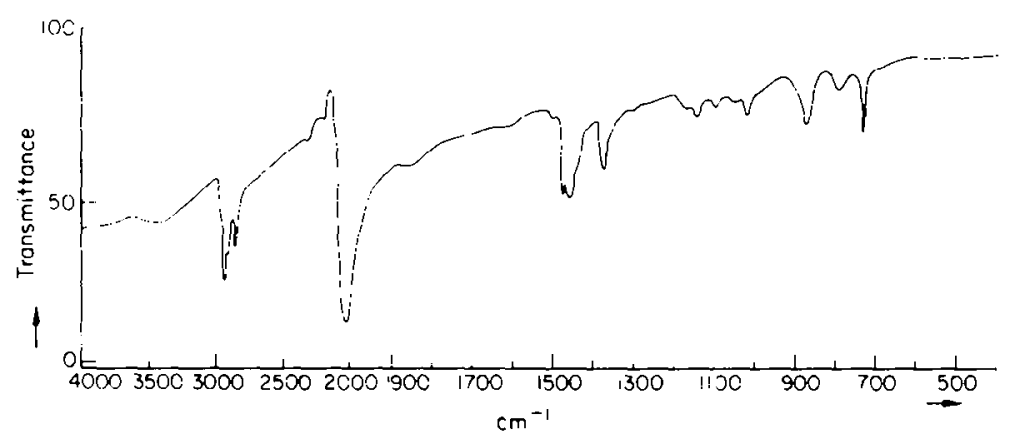

Fig. 5. I.R. spectrum of $\left[\operatorname{Re}_{2}(\mathrm{SeCN})_{8}\right]\left[\left(n-\mathrm{C}_{4} \mathrm{H}_{4}\right)_{4} \mathrm{~N}\right]_{2 .}$.

aid of only the position and nature of $\nu(\mathrm{CN})$. It is possible to distinguish the two forms by the combined evidence of $\nu(\mathrm{C}-\mathrm{Se})$ and $\delta(\mathrm{SeCN})$, although the former is very weak in $\mathrm{M}-\mathrm{NCSe}$ complexes. $\nu(\mathrm{C}-\mathrm{Se})$ lies in the range $672-606 \mathrm{~cm}^{-1}$. In our spectrum the $\mathrm{C}$-Se stretching vibration was not observed and this could be an indication that the selenocyanato groups were $N$ bonded [22].

The other recorded spectra were used as a control on the purity of the pre-

22. D. M. Adams, Metal-ligand and Related Vibrations, p. 319 (1967). 
pared compounds. Specific bands for the cations are:

$$
\begin{array}{ll}
{\left[\left(n-\mathrm{C}_{4} \mathrm{H}_{9}\right)_{4} \mathrm{~N}\right]^{+}} & \mathrm{N}-\mathrm{C} \text { (stretching) at } 1030 \mathrm{~cm}^{-1} \\
{\left[\left(\mathrm{C}_{6} \mathrm{H}_{5}\right)_{4} \mathrm{P}\right]^{+}} & \mathrm{P}-\mathrm{C} \text { (stretching) at } 530 \mathrm{~cm}^{-1} \\
{\left[\left(\mathrm{C}_{6} \mathrm{H}_{5}\right)_{4} \mathrm{As}\right]^{+}} & \text {As-C (stretching) at } 460 \mathrm{~cm}^{-1} \\
{\left[\left(\mathrm{C}_{6} \mathrm{H}_{5}\right)_{4} \mathrm{Sb}\right]^{+}} & \text {Sb-C (stretching) at } 430 \mathrm{~cm}^{-1}
\end{array}
$$

Acknowledgement - The assistance of Mr. J. P. Hoekstra with the magnetic measurements is gratefully acknowledged. Mrs. B. Uithol is thanked for her experimental assistance. I appreciate the possibility given by Professor W. van Gool to participate in the "Pattern Building Project" and I gratefully acknowledge his continuous interest.

The investigations were supported in part by the Netherlands Foundation for Chemical Research (SON) with financial aid from the Netherlands Organization for the advancement of Pure Research (ZWO). 